\title{
Organic Manures and Bio-inoculants Mediated Influence on growth and Flowering of African Marigold (Tagetes erecta L.) cv. Pusa Narangi Gainda
}

\author{
Swathi, K. ", Indrajit Sarkar, Soumen Maitra and Sachin Sharma
}

Dept. of Floriculture, Medicinal and Aromatic Plants, Faculty of Horticulture, UBKV, Pundibari, Cooch Behar, W.B. (736 165), India

\section{Corresponding Author}

Swathi, K.

e-mail: kswathi006@gmail.com

\author{
Article History \\ Manuscript No. AR1690a \\ Received in $15^{\text {th }}$ September, 2016 \\ Received in revised form $18^{\text {th }}$ May, 2017 \\ Accepted in final form $6^{\text {th }}$ June, 2017
}

\begin{abstract}
Marigold (Tagetes sp.) is an ornamental annual suitable for commercial cultivation in Indian plains as a loose flower. West Bengal is considered as a prominent producer of this flower in India. In northern part of West Bengal due to suitability of agro-climatic condition enormous scope for commercial cultivation of African marigold has already been realized. The present experiment was carried out at Instructional Farm of Faculty of Horticulture under Uttar Banga Krishi Viswavidyalaya during winter season of 2015-2016 with the organic sources which are easily available eco friendly and sustainable. The experiment was laid out in Randomized Block design containing seven treatments comprising of poultry manure, farm yard manure, vermicompost, mustard oil cake and bio-fertilizer like Azotobactor, phosphorous solubilizing bacteria along with control replicated thrice with a seedlings of twenty eight days old were transplanted in a plot size of $2 \times 2 \mathrm{~m}^{2}$ following a spacing of $45 \times 30 \mathrm{~cm}^{2}$. Results revealed that application of organic sources at optimum dosage showed an increased and improved results interms of growth and flowering as compared to control. Among all the treatments poultry manure at $15 \mathrm{t} \mathrm{ha}^{-1}$ significantly improved the plant height, plant spread, branch production leaf chlorophyll content, earliness in flowering, duration of flowering, floriferousness, fresh weight of flowers and obviously the flower yield of African marigold followed by mustard oil cake application as foliar application.
\end{abstract}

Keywords: African marigold, organic farming, eco-friendly, Azotobacter, PSB

\section{Introduction}

Marigold (Tagetus spp.) is a versatile flower which is gaining importance as ornamental as well as in industrial sector due to its multipurpose uses. As an ornamental, marigold is used as loose flower, cut flower, flower beds in herbaceous border (Raghava, 2000). Apart from these both the leaves and flowers are used due to their medicinal property. Essential oil extracted from marigold is used in perfumery industry and also acts like fly repellent. The ground blossom meal of petals is being feed to poultry birds to obtain dark orange colored yolk in eggs (Bosma et al., 2003). Owing to its importance, commercial cultivation of marigold is confined to states like Karnataka, Gujarat, Maharastra, Haryana, Andhra Pradesh, Tamil Nadu, Uttar Pradesh, West Bengal, Odisha and Chattisgarh etc. It occupies an area of 55, 890 ha with a production of 5, 11, 310 metric tons loose flowers (Indian Horticulture database, 2014). West Bengal with its varied agroclimatic zones facilitates the growth of this crop in entire state. Among this it is widely grown in the districts of Nadia, Midnapore, Howrah, Hooghly and 24 Paraganas. In northern part of West Bengal there is enormous demand for this crop and the agroclimatic conditions of this part is suitable for successful cultivation of marigold.

Demand for Organic floriculture is increasing among the growers and consumers owing to its quality, yield, safe and flavour. Eco friendly nature and cheap availability of organic manures provide healthy environment and also reduce the investment made on chemical fertilizers Tiyagi et al. (2015). Organic farming helps in improvement of soil health, proper energy flow in soil, crop, water environment system, keeps biological life cycle alive and helps in sustaining considerable levels in yield. According to Kabir et al. (2011) the sustainability of organics is based on the principles of restoration of soil organic matter in the form of humus, increasing microbial population, skilful application of the factors contributing soil life and health by aggregation, aeration, permeability and water holding capacity, which further promote growth and development of plants. Bio-fertilizers are the products containing living cells of different types of micro organisms, which are capable of mobilizing nutritive elements from non-usable form to usable form through biological process (Kader et al., 2002).

Organic practices by means of poultry manure, farm yard manure, vermicompost, mustard oil cake and bio-fertilizers 
like Azotobacter, Phosphate Solubilizing Bacteria (PSB) have been taken to study the efficacy of different organic manures on growth and flowering of African marigold (Tagetus erecta) cv. Pusa Narangi Gainda in Terai agro-climatic zone of West Bengal.

\section{Materials and Methods}

The experiment was carried out at Instructional Farm of Faculty of Horticulture under Uttar Banga Krishi Viswavidyalaya for a period of six months during 2015-2016. Various physical and chemical properties of the soil of the experimental site was as follows sand- $63.740 \%$, silt-19.795\%, clay-16.465\%, pH-5.93, organic carbon-1.015\%, available nitrogen-197.795 kg ha-1, available phosphorous-46.005 kg $\mathrm{ha}^{-1}$ and available potassium-94.07 $\mathrm{kg} \mathrm{ha}^{-1}$. The experiment laid out in randomized block design with three replications. Seedlings of African marigold cv. Pusa Narangi Gainda were raised in nursery beds and the seedlings of twenty eight days were transplanted to the main field with a plot size of $2 \times 2$ $\mathrm{m}^{2}$ following a spacing of $45 \times 30 \mathrm{~cm}^{2}$ during second week of September, 2015. All the manures, except mustard oil cake were applied at the time of final land preparation. The well fermented mustard oil cake was applied after two weeks of transplanting as foliar spray. Due to low phosphorous content of the soil, in a treatment only PSB was used to upgrade phosphorus status and as well as in other treatments also plants are subjected to grow based on their inherent nutrient ability along with different organic sources to compare their role in growth and flowering. The treatments consists of $T_{1}$ Control, $\mathrm{T}_{2}$-Farm Yard Manure @ $7.5 \mathrm{t} \mathrm{ha}^{-1}, \mathrm{~T}_{3}$-Vermi-compost @ $10 \mathrm{t} \mathrm{ha}{ }^{-1}, \mathrm{~T}_{4}$-Mustard oil cake @ $12.5 \mathrm{t} \mathrm{ha}^{-1}, \mathrm{~T}_{5}$-Poultry manure @ $15 \mathrm{tha}^{-1}, \mathrm{~T}_{6}$-Phosphorous solubiliging Bacteria (PSB) @ $8 \mathrm{~kg} \mathrm{ha}^{-1}, \mathrm{~T}_{7}$-Azotobacter @ $8 \mathrm{~kg} \mathrm{ha}^{-1}$ and their individual nutrient composition comprises of Farm Yard Manure (N-0.5\%, P-0.2\%, K- 0.5\%,) Vermi-compost (N-3\%, P-1.0\%, $1.5 \%)$, Mustard oil cake-(N-5.2\%, P-1.8\%, K-1.2\%), Poultry manure-(N-3.03\%, $\mathrm{P}-2.63 \%, \mathrm{~K}-1.4 \%)$. All the cultural practices were performed accordingly. Observations were recorded on various vegetative and reproductive parameters were collected from ten randomly selected plants and statistically analyzed by using the software OPSTAT.

\section{Results and Discussion}

\subsection{Growth characters}

Amongst the different organic manures used, application of poultry manure gave a significant effect on plant height (77.62 $\mathrm{cm})$, plant spread in both $\mathrm{N}-\mathrm{S}$ and $\mathrm{E}-\mathrm{W}$ direction $(35.75 \mathrm{~cm}$ and $32.66 \mathrm{~cm}$ ) and number of primary branches plant ${ }^{-1}(14.11)$ followed by mustard oil cake respectively (Table 1). Similar results were also found in marigold was well documented by Idan et al., (2014). Poultry manure is the abundant source of plant nutrients such as nitrogen, phosphorous, potassium and other essential nutrients (Garg and bahal, 2008). Nitrogen is the essential part in nucleic acid, plays an important role in
Table 1: Effect of different organic manures on growth characters of African marigold (Tagetus erecta) cv. Pusa Narangi Gainda

\begin{tabular}{lccccc}
\hline \multirow{2}{*}{ Treatment } & $\mathrm{PH}$ & \multicolumn{2}{c}{ Plant spread $(\mathrm{cm})$} & NPB & $\mathrm{CC}$ \\
\cline { 3 - 4 } & & $(\mathrm{N}-\mathrm{S})$ & $(\mathrm{E}-\mathrm{W})$ & & \\
\hline $\mathrm{T}_{1}$ & 53.05 & 26.08 & 27.66 & 11.69 & 49.793 \\
$\mathrm{~T}_{2}$ & 67.34 & 27.33 & 27.00 & 13.72 & 51.417 \\
$\mathrm{~T}_{3}$ & 70.51 & 28.78 & 30.83 & 12.61 & 56.423 \\
$\mathrm{~T}_{4}$ & 73.83 & 34.14 & 32.00 & 13.94 & 53.087 \\
$\mathrm{~T}_{5}$ & 77.62 & 35.75 & 32.66 & 14.11 & 59.480 \\
$\mathrm{~T}_{6}$ & 51.50 & 33.75 & 30.00 & 11.83 & 47.357 \\
$\mathrm{~T}_{7}$ & 49.59 & 28.71 & 28.72 & 11.76 & 46.773 \\
$\mathrm{SEm} \pm$ & 1.115 & 1.17 & 1.27 & 0.56 & 0.905 \\
$\mathrm{CD}(p=0.05)$ & 3.474 & 3.64 & NA & 1.76 & 2.819 \\
\hline
\end{tabular}

$\mathrm{PH}$ : Plant height $(\mathrm{cm})$ at $80 \mathrm{DAP}$; NPB: No. of primary branches plant ${ }^{-1}$; CC: Chlorophyll content (spad value)

protein components and enzymes and organizes hormone activity which is important in cell division and stimulates biological processes (Pooja and Kumari, 2012). Due to its higher content of major plant nutrients, considerable amount of nitrogen in the form of uric acid which is readily available to the plants and narrow $\mathrm{C}: \mathrm{N}$ ratio than other manures facilitates the increased growth interms of plant height, plant spread (both $\mathrm{N}-\mathrm{S}$ and $\mathrm{E}-\mathrm{W}$ ), number of primary branches plant ${ }^{-1}$. Increased number of branches plant ${ }^{-1}$ might be due to the absorbed nitrogen combined with carbohydrate synthesis led to the formation of nitrogenous compounds such as proteins, amino acids, nucleic acids, various enzymes and co-enzymes which were responsible for cell division and cell enlargement results in more number of branches plant ${ }^{-1}$ (Chaudhary, 2007).

Next to poultry manure, mustard oil cake gave a significant effect on increased plant growth. Mustard oil cake is the byproduct of mustard oil seed crop. Oil cakes are the important and quick acting organic amendment replaces the use of chemical fertilizers and pesticides by suppressing pathogens and insects. Proper decomposition of oil cakes and mineralization, it supplies available nutrients directly to the plant and also maintains the soil structure and rhizosphere environment (Sultana and Ghaffar, 2010). The results are also in conformity with the results of Rafi et al. (2016). Vermi-compost contains plant growth substances such as plant growth hormone, produced by earth warms during vermicomposting and also contains relatively more amount of nitrogen, carbon and mineral sources. Significant results with the application of vermicompost were also made by Sangwan et al. (2010) in marigold. FYM provides adequate plant nutrients and improves the physico-chemical properties of the soil and as a sustainable source for the improvement of soil fertility and productivity. 


\subsection{Leaf chlorophyll content}

Highest chlorophyll content was observed in poultry manure (59.48) followed by vermicompost (56.42) and it was least in control (46.77). It may be due to the reason that phosphorous is a constituent of chlorophyll and is involved in many biological processes including cell division, development of meristematic cells, photosynthesis etc. As a rich source of phosphorous, application of poultry manure resulted in higher chlorophyll content. According to Elhindi (2012) organic matter includes essential nutrients for plant growth which has a positive effect for chlorophyll molecules and chloroplast formation. Organic acids and carbon dioxide have a role in enhancing the availability of some nutrients such as Mg which plays an important role in the formation of the chlorophyll molecule.

\subsection{Flowering attributes}

The observations like days to first flower bud appearance (69.33), days to full bloom (80.56), were earlier in case of poultry manure application followed by mustard oil cake (70.72, 82.67 respectively) and FYM (Table 2). This might be due to the increased vegetative growth and balanced $\mathrm{C}: \mathrm{N}$ ratio could lead to increased synthesis of carbohydrate which eventually promoted greater flowering. Duration of flowering was almost at par with these organic sources i.e., 24 days. It may be due to differences in their source and nutrient availability to the plant. Increase in phosphorous is found to be involved in the initiation of floral primordial formation leading to increase in flower diameter.

Table 2: Effect of different organic manures on flowering characters of African marigold (Tagetus erecta) cv. Pusa Narangi Gainda

\begin{tabular}{lcccc}
\hline Treatment & DFFBA & DFB & DF & FD \\
\hline $\mathrm{T}_{1}$ & 77.41 & 93.90 & 18.40 & 4.64 \\
$\mathrm{~T}_{2}$ & 71.55 & 84.51 & 21.50 & 5.29 \\
$\mathrm{~T}_{3}$ & 73.32 & 85.62 & 24.12 & 5.50 \\
$\mathrm{~T}_{4}$ & 70.72 & 82.67 & 24.89 & 6.06 \\
$\mathrm{~T}_{5}$ & 69.33 & 80.56 & 24.01 & 8.74 \\
$\mathrm{~T}_{6}$ & 74.30 & 87.48 & 19.56 & 4.74 \\
$\mathrm{~T}_{7}$ & 75.25 & 89.48 & 20.73 & 4.99 \\
$\mathrm{SEm} \pm$ & 0.649 & 0.385 & 0.336 & 0.073 \\
$\mathrm{CD}(p=0.05)$ & 2.021 & 1.201 & 1.045 & 0.226 \\
\hline
\end{tabular}

DFFBA: Days to first flower bud appearance; DFB: Days to full blooming; DF: Duration of flowering; FD: Flower diameter $(\mathrm{cm})$

\subsection{Yield attributes}

Data presented in Table 3 represents that remarkable number of flowers plant ${ }^{-1}$ (55.66), fresh weight of ten flowers (63.74 g) was more with the application of poultry manure followed by mustard oil cake 43.34 and 81.49 g respectively. Significant
Table 3: Effect of different organic manures on flower yield characters of African marigold (Tagetus erecta) cv. Pusa Narangi Gainda

\begin{tabular}{lccccc}
\hline Treatment & NFP & FWF & FYP & FYP $^{*}$ & FYH \\
\hline $\mathrm{T}_{1}$ & 29.39 & 43.09 & 126.66 & 3.80 & 9.50 \\
$\mathrm{~T}_{2}$ & 37.11 & 54.71 & 203.06 & 6.09 & 15.23 \\
$\mathrm{~T}_{3}$ & 39.33 & 68.98 & 271.33 & 8.14 & 20.35 \\
$\mathrm{~T}_{4}$ & 43.34 & 81.49 & 353.2 & 10.59 & 26.49 \\
$\mathrm{~T}_{5}$ & 55.66 & 63.74 & 354.71 & 12.75 & 31.89 \\
$\mathrm{~T}_{6}$ & 34.83 & 43.16 & 150.36 & 5.01 & 12.53 \\
$\mathrm{~T}_{7}$ & 37.30 & 40.21 & 150.01 & 4.50 & 11.26 \\
$\mathrm{SEm} \pm$ & 1.784 & 0.530 & 4.753 & 1.422 & 1.004 \\
$\mathrm{CD}(p=0.05)$ & 5.559 & 1.652 & 14.80 & 4.431 & 3.128 \\
\hline
\end{tabular}

NFP: No. of flowers plant ${ }^{-1}$; FWF: Fresh weight of 10 flowers

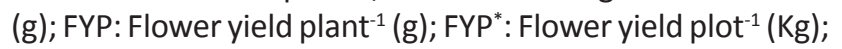
FYH: Flower yield ha-1 $(\mathrm{t})$

difference was observed among the treatments with respect to flower yield plant ${ }^{-1}$ which was highest in poultry manure (354.71 g) followed by mustard cake (353.2 g) and lowest in case of control (126.66 g). The availability of major nutrients, protein and other growth substances, enzymes of these organic sources consequently resulted in increased flower yield. These results are in conformity with the findings of Bhat et al. (2010) in African marigold. The above findings FYM and vermicompost are at par with the results of Prakash et al., (2014) in pot marigold. Among all the organic manures, the application of poultry manures gave maximum net returns up to ₹ $2,16,250 \mathrm{ha}^{-1}$ (Table 4). This was closely followed by mustard cake ( $₹ 1,77,400$ ha $\left.^{-1}\right)$ and vermicompost $(1,31,850$ $\left.\mathrm{ha}^{-1}\right)$. The other treatments showed gave a less returns but the population of beneficial soil microorganisms as well as soil properties can be improved.

Table 4: Effect of different organic manures on economics of African marigold (Tagetus erecta) cv. Pusa Narangi Gainda

\begin{tabular}{lcccc}
\hline Treatment & CC & GI & NI & $\begin{array}{c}\mathrm{B}: \mathrm{C} \\
\text { ration }\end{array}$ \\
\hline $\mathrm{T}_{1}$ & 77.41 & 93.90 & 18.40 & 4.64 \\
$\mathrm{~T}_{2}$ & 71.55 & 84.51 & 21.50 & 5.29 \\
$\mathrm{~T}_{3}$ & 73.32 & 85.62 & 24.12 & 5.50 \\
$\mathrm{~T}_{4}$ & 70.72 & 82.67 & 24.89 & 6.06 \\
$\mathrm{~T}_{5}$ & 69.33 & 80.56 & 24.01 & 8.74 \\
$\mathrm{~T}_{6}$ & 74.30 & 87.48 & 19.56 & 4.74 \\
$\mathrm{~T}_{7}$ & 75.25 & 89.48 & 20.73 & 4.99 \\
\hline
\end{tabular}

CC: Cost of cultivation ( $₹ \mathrm{ha}^{-1}$ ); GI: Gross income (₹ ha $\left.{ }^{-1}\right)$; NI: Net income (₹ ha-1); 


\section{Conclusion}

Poultry manure gave superior results on various parameters as plant height $(77.62 \mathrm{~cm})$, number of primary branches plant ${ }^{-1}$ (14.11), chlorophyll content (59.48), early appearance of flower bud and days to full bloom, number of flowers plant ${ }^{-1}$ (55.66) and flower yield plant ${ }^{-1}\left(354.71 \mathrm{t} \mathrm{ha}^{-1}\right)$. Mustard oil cake also gave good results and remarkable flower yield (26.49 $\mathrm{t} \mathrm{ha}^{-1}$ ) and flowers remain fresh for longer days as compared to other treatments. Hence poultry manure and mustard oil cake can be used for commercial cultivation of marigold and other flower crops of this region.

\section{References}

Bhat, D.J., Sheetal Dogra Pandey, R.K., Sharma, J.P., Jamwal, S., 2010. Influence of integrated nutrient management on growth, flowering and yield of African marigold cv. Pusa Narangi Gainda. Environment and Ecology, 28 (1A), 466-468.

Bosma, T.L., Dole, J.M., Maness, N.O., 2003. Optimizing marigold (Tagetes erecta L.) petal and pigment yield. Crop Science 43(6), 2118-2124.

Chaudhary, S.V.S., 2007. Effect of nitrogen, phosphorous and bio-fertilizers application on plant growth and bulb production in tuberose. Haryana Journal of Horticultural Sciences 36(1\&2), 82-85.

Elhindi, K., 2012. Evaluation of composted green waste fertigation through surface and subsurfacedrip irrigation systems on pot marigold plants (Calendula officinalis L.) grown on sandy soil. Australian Journal Crop Science 6(8), 1249-1259.

Garg, S., Bahla, G.S., 2008. Phosphorous availability to maize as influenced by organic manures. Bioresource Technology 99, 773-777.

Rafi, H., Dawar, S., Tariq, M., 2016. Combined effect of soil amendment with oil cakes and seed priming in the control of root rot fungi of leguminous and nonleguminous crops. Pakistan Journal of Botany 48(3), 1305-1311.
Kabir, A.K.M., Iman, M.H., M.M.H., Mondal, Choudary, S., 2011. Response of tuberose to integrated nutrient management. Journal of Environmental Science and Natural Resources 4(2), 55-59.

Kader, M.A., Mian, M.H., Hoque, M.S., 2002. Effects of Azotobacter inoculants on yield and nitrogen uptake by wheat. On line Journal of Biological Sciences 2, 259-261.

Pooja, G.S., Kumari, D.S.N., 2012. Response of African marigold (Tagetus erecta) to integrated nutrient management. Annals of Biology 28(1), 66-67.

Prakash, P., Pant, K.S., Yewale, A.A., 2014. Effect of tree spacing and organic manures on various growth parameters of Calendula officinalis L. under Grewia optiva based agroforestry system. International Journal of Farm Sciences 4(2), 130-138.

Sangwan, P., Garg, V.K., Kaushik, C.P., 2010. Growth and yield response of marigold to potting media containing vermicompost produced from different wastes. Environmentalist 30, 123-130.

Raghava, S.P.S., 2000. Marigold versatile crop with golden harvest. Floriculture Today 5(11), 40-41.

Razzaq, O.I., Prasad, V.M., Saravanan, S., 2014. Effect of organic manures on flower yield of African marigold (Tagetes erecta L.) cv. Pusa Narangi Gainda. International Journal of Agricultural Science and Research 4(1), 39-50.

Indian Horticulture Database, 2014. Ministry of Agriculture, Government of India, 286.

Sultana, N., Ghaffar, A., 2010. Effect of fungicides, microbial antagonists and oil cakes in the control of Fusarium solani, the cause of seed rot, seedling and root infection of bottle gourd, bitter gourd and cucumber. Pakistan Journal of Botany 42(4), 2921-2934.

Tiyagi, S.A, Safiuddin, R., Rizvi, I., Mahamood Khan, Z., 2015. Evaluation of organic matter, bio-inoculants and inorganic fertilizers on growth and yield attributes of tomato with to the management of plant parasitic nematodes. Emirates Journal of Food and Agriculture 27, 602-609. 